\title{
Ranitidine treatment inducing methemoglobinemia in male Wistar rats
}

\author{
Wilson Roberto Malfará*, Ana Maria de Souza, Regina Helena Costa Queiroz
}

Departamento de Análises Clínicas, Toxicológicas e Bromatológicas, Faculdade de Ciências Farmacêuticas de Ribeirão Preto, Universidade de São Paulo

\section{*Correspondence:}

W. R. Malfará

Departamento de Análises Clínicas,

Toxicológicas e Bromatológicas

Faculdade de Ciências Farmacêuticas

de Ribeirão Preto, Universidade de São

Paulo

Avenida do Café s/n - Monte Alegre

14040-903 Ribeirão Preto-São Paulo. Brasil.

E-mail:wilsonmalfara@yahoo.com.br
Drug idiosyncrasy is an adverse event of unknown etiology that occurs in a small fraction of people taking a drug. The histamine2 (H2)-receptor antagonist ranitidine causes idiosyncratic reactions in patients. To investigate the hypothesis that ranitidine could induce hematological toxic effects, the drug was administered intraperitoneally (ip) to two of six groups of 200-220 g male Wistar rats $(n=6)$. Group I received as single dose of saline solution ( $\mathrm{NaCl}$, $200 \mu \mathrm{L}$ ) Group II received $200 \mu \mathrm{L}$ of $\mathrm{NaCl}$, ip, at 0, 24, 48 and $72 \mathrm{~h}$, Group III (controls of the vehicle) received as single dose of dimethyl sulfoxide (DMSO, 200 $\mu$ L), ip, Group IV (controls of the vehicle) received $200 \mu \mathrm{L}$ of DMSO, ip, at 0, 24, 48, and $72 \mathrm{~h}$, Group V received a single dose of $100 \mathrm{mg} / \mathrm{kg}$ of ranitidine in $200 \mu \mathrm{L}$ of DMSO) ip, Group VI received $50 \mathrm{mg} / \mathrm{kg}$ of ranitidine, in $200 \mu \mathrm{L}$ of DMSO, ip, at 0, 24, 48, and $72 \mathrm{~h}$. Erythrograms, leucograms were measured; percent methemoglobin content of the blood was analyzed spectophotometrically. Methemoglobinemia increased to a significant extent following ranitidine treatment, in both study groups. White blood cell and neutrophil counts showed a discrete reduction following either regime of treatment. A marginal mobilization of the neutrophil pool probably occured. Following the multiple dose regime, leukocyte counts increased, but their distribution maintenance profile remained the same. The administration of ranitidine to rats induces methemoglobinemia in the administered doses, suggesting that from a certain concentration and dosage scheme the substance can be methemeglobinemia inductor.

\section{Uniterms}

- Ranitidine

- Methemoglobinemia

- Hematologic abnormalities

\section{INTRODUCTION}

Adverse drug reactions of unknown etiology that occur in a small fraction of the treated population are defined as idiosyncratic. These reactions are typically unpredictable, show no obvious relation to dose, and display a variable time to onset in relation to start of drug therapy. Idiosyncratic reactions cause not only human 
suffering but also sometimes result in curtailing use of otherwise effective therapeutic agents (Luyendyk et al., 2003).

Idiosyncratic drug responses are commonly thought to arise either from drug metabolism polymorphism or from an allergic response to a drug or its metabolite(s). However, for the majority of drugs, supporting evidence for either of these hypotheses is lacking (Luyendyk et al., 2003).

Histamine $\mathrm{H}_{2}$-receptor antagonists are widely used in the treatment of gastrointestinal diseases related to gastric acid hypersecretion and cytoprotective effects (Penston, Wormsley, 1986; Aymard et al., 1988; MunozArrebola et al., 1989). Ranitidine, one of such antagonists was first marketed in 1981; since then, many patients have been treated with this drug, and much experience regarding its safety has been gathered (Vial et al., 1991).

A wide array of ranitidine side effects of infrequent incidence has been reported; among them, are several cases of mixed hepatitis of which very few have been welldocumented. Ranitidine-associated acute hepatitis has been estimated to occur in less than 1 per 100,000 patients (Penston, Wormsley, 1986). Following long-term treatment of prepyloric or duodenal ulcer with $2 \times 150 \mathrm{mg}$ of ranitidine daily, a total of 6 adverse effects were observed in 5 (18.7\%) out of 32 patients (Meryn et al., 1983).

Mikawa et al. (1999), found that while cimetidine and famotidine slightly reduced $\mathrm{O}_{2}^{-}$and $\mathrm{H}_{2} \mathrm{O}_{2}$ production by neutrophils, in a dose-dependent manner, ranitidine failed to do so, and did not appear to have any deleterious effect on neutrophil function, an important consideration for its use in severely ill patients.

In a study using Sprague-Dawley rats, ranitidine was administered orally at doses of 30, 100, 300 and $1000 \mathrm{mg} / \mathrm{kg}$. Animals surviving this dose, presented increased salivation, decreased body weight gain, increased water consumption, increased urinary $\mathrm{Na}$ and $\mathrm{K}$ excretion, as well as increased serum albumin content and increased liver, kidney and heart weights (Takeuchi et al., 1983).

A case of leukocytosis and eosinophilia has been reported by Gelwan et al. (1986), in a patient receiving ranitidine therapy.

Nakada et al. (1996) concluded that acute renal failure is one of the risk factors of ranitidine neurotoxicity, and that increased sensitivity of the central nervous system to the drug may contribute towards its toxicity in renal failure.

Luyendyk et al. (2003) in co-treatment of rats with LPS and ranitidine resulted in the expected hepatocellular damage as marked by increases in serum ALT and AST activities and cholestatic injury as increases in serum GGT activity, likely to cause idiosyncratic reactions.

In view of the various reports on adverse effects of ranitidine, we decided to test the drug at respectively single and multiple dose regimes, for effects on hematological parameters and percent increase of methemoglobin in the male Wistar rat.

\section{MATERIAL AND METHODS}

\section{Animals}

Ranitidine was administered intraperitoneally (ip) to six groups of 6 animals each, of 200-220 g male Wistar rats $(n=6)$. Group I received a single dose of saline solution $(\mathrm{NaCl}, 200 \mu \mathrm{L})$ Group II received $200 \mu \mathrm{L}$ of $\mathrm{NaCl}$, ip, at 0 , 24, 48 and $72 \mathrm{~h}$, Group III (controls of the vehicle) received as single dose of dimethyl sulfoxide (DMSO, $200 \mu \mathrm{L}$ ), ip, Group IV (controls of the vehicle) received $200 \mu \mathrm{L}$ of DMSO, ip, at $0,24,48$, and $72 \mathrm{~h}$, Group V received a single dose of $100 \mathrm{mg} / \mathrm{kg}$ of ranitidine (Glaxo-Wellcome, S.Paulo, Brazil) in $200 \mu \mathrm{L}$ of DMSO) ip, Group VI received $50 \mathrm{mg} / \mathrm{kg}$ of ranitidine, in $200 \mu \mathrm{L}$ of DMSO, ip, at 0, 24, 48, and $72 \mathrm{~h}$. Two hours following treatment, animals were anesthetized with ethyl ether, and blood was collected from the aorta, and used for the determination of hematological parameters and methemoglobinemia.

\section{Analytical procedures}

Hematological measurements included: manual red cell and leukocyte counts (in Neubauer hemocytometer), hematocrit (microhematocrit method), hemoglobin (cyanomethemoglobin method), calculations of red indices, differential leukocyte count (in blood smears stained with Leishman) and reticulocyte count (with the supravital dye brilhant crezyl blue) (Coates, 1995).

All blood samples were assayed for methemoglobin levels relative to hemoglobin levels, by the spectrophotometer technique of Grossman and Jollow (1988) and Coleman et al. (1991).

\section{Statistical analyses}

Data were analyzed by ANOVA and by multiple post-test comparisons according to Tukey-Kramer, using the GraphPad Instat and Statgraphics software, the level of significance being set at $<0.05$.

\section{RESULTS}

No significant differences were observed when we compare the groups that received saline solution $(\mathrm{NaCl})$ in single doses and multiple doses with the groups that 
received DMSO (Table I). We compare then the animals that received DMSO and those that received the drugs. Within 2 hours following the administration of a single dose of $100 \mathrm{mg} / \mathrm{kg}$ or of $50 \mathrm{mg} / \mathrm{kg}$ in multiple doses of ranitidine, rapid, acute methemoglobinemia resulted, showing values of $5.80 \pm 0.84 \%$ and $6.50 \pm 0.84 \%$, respectively compared to control values of $1.19 \pm 0.21$ and $4.22 \pm 0.80 \%$, respectively (Table I). Methemoglobin levels increased significantly after administration of either concentration, suggesting a dose-dependent methemoglobinemic toxic effect of ranitidine (Figure 1).

However, no significant differences in hematological parameters of the red or white cell series was observed in the groups studied (Tables I and II, respectively).

\section{DISCUSSION}

Ranitidine is a $\mathrm{H}_{2}$-receptor antagonist that has been in use for the treatment of gastrointestinal diseases for over a decade, thanks to the lack of serious adverse reactions and a long required dosage interval (Fischer, Counteur, 2001).
Adverse reactions to drugs can be divided into two categories. The first occurs when the reaction bears no relation to the mode of action of the drug and occurs well within the intended dosage range. This type of reaction is often termed idiosyncratic, idiopathic or hypersensitivity.

A widely used drug associated with idiosyncratic hepatotoxicity is the histamine -2 (H2)-receptor antagonist ranitidine (Luyendyk et al., 2003).

Lewis (1987) after having given ranitidine to tens of millions of patients, reported that its hepatic toxicity supports such a low incidence, and that ranitidine-induced hepatic injury is presumably due to hypersensitivity. Few clinical reports implicate ranitidine as the cause of a predominately cholestatic hepatitis, which resembles ascending cholangitis, by predominantly presenting fever and rigors. Eosinophil infiltration in the liver and a response to rechallenge in some cases, suggest an immunological mechanism for its pathogenesis. A direct toxic action is also probable: $\mathrm{H}_{2}$-blockers are toxic to isolated hepatocytes in vitro, and also inhibit bile flow. Granulatomatous infiltration of the liver has been shown to be evoked by a number of drugs, including ranitidine. This effect sometimes occurs

TABLE I - Comparison of hematological parameters (red series) for ranitidine $100 \mathrm{mg} / \mathrm{kg}$ administered in single dose and ranitidine $50 \mathrm{mg} / \mathrm{kg}$ administered in multiple doses with control groups (DMSO).

\begin{tabular}{|c|c|c|c|c|c|c|}
\hline $\begin{array}{l}\text { Hematological } \\
\text { parameters }\end{array}$ & $\begin{array}{l}\text { Control }(\mathrm{n}=6) \\
\mathrm{NaCl} \\
\text { Single dose } \\
\text { mean } \pm \mathrm{SD}\end{array}$ & $\begin{array}{l}\text { Control }(\mathrm{n}=6) \\
\mathrm{NaCl} \\
\text { Multiple dose } \\
\text { mean } \pm \mathrm{SD}\end{array}$ & $\begin{array}{l}\text { Control }(\mathrm{n}=6) \\
\text { DMSO } \\
\text { Single dose } \\
\text { mean } \pm \text { SD }\end{array}$ & $\begin{array}{l}\text { Ranitidine } 100 \\
(\mathrm{n}=6) \\
\text { Single dose } \\
\text { mean } \pm \mathrm{SD}\end{array}$ & $\begin{array}{l}\text { Control }(n=6) \\
\text { DMSO } \\
\text { Multiple dose } \\
\text { mean } \pm \text { SD }\end{array}$ & $\begin{array}{l}\text { Ranitidine } 50 \\
(\mathrm{n}=6) \\
\text { Multiple dose } \\
\text { mean } \pm \text { SD }\end{array}$ \\
\hline $\begin{array}{l}\text { Erythrocytes } \\
\text { (millions } / \mathrm{mm}^{3} \text { ) }\end{array}$ & $5.25 \pm 0.27$ & $5.30 \pm 0.40$ & $5.00 \pm 0.12$ & $5.10 \pm 0.19$ & $4.98 \pm 0.37$ & $4.95 \pm 0.41$ \\
\hline Hematocrit (\%) & $42.50 \pm 1.85$ & $46.30 \pm 2.10$ & $44.33 \pm 1.21$ & $45.50 \pm 1.87$ & $44.6 \pm 1.23$ & $43.5 \pm 2.42$ \\
\hline $\operatorname{Hemoglobin}(\mathrm{g} / \mathrm{dl})$ & $14.9 \pm 1.20$ & $14.25 \pm 0.65$ & $14.7 \pm 0.80$ & $14.51 \pm 0.40$ & $14.03 \pm 1.57$ & $13.66 \pm 1.31$ \\
\hline $\begin{array}{r}\text { Mean corpuscular } \\
\text { hemoglobin }(\mathrm{pg})\end{array}$ & $28.57 \pm 1.85$ & $27.35 \pm 0.95$ & $29.03 \pm 1.58$ & $28.23 \pm 0.48$ & $28.11 \pm 1.67$ & $27.51 \pm 1.29$ \\
\hline $\begin{array}{l}\text { Mean corpuscular } \\
\text { hemoglobin } \\
\text { concentration } \\
(\mathrm{g} / \mathrm{dl})\end{array}$ & $32.00 \pm 1.52$ & $30.10 \pm 1.12$ & $33.00 \pm 1.09$ & $31.57 \pm 0.87$ & $30.50 \pm 1.35$ & $29.91 \pm 1.01$ \\
\hline $\begin{array}{l}\text { Mean corpuscular } \\
\text { volume (fl) }\end{array}$ & $87.63 \pm 1.20$ & $88.50 \pm 1.15$ & $89.63 \pm 1.41$ & $89.43 \pm 1.56$ & $91.12 \pm 1.67$ & $90.08 \pm 2.67$ \\
\hline Reticulocytes (\%) & $3.25 \pm 0.85$ & $3.15 \pm 1.70$ & $3.08 \pm 0.30$ & $2.50 \pm 1.22$ & $2.89 \pm 0.87$ & $2.91 \pm 0.43$ \\
\hline $\begin{array}{l}\text { Methemoglobin (\%) } \\
\text { single dose }\end{array}$ & $1.54 \pm 0.13$ & $3.95 \pm 0.35$ & $1.19 \pm 0.21$ & $5.80 \pm 0.84 * *$ & $4.22 \pm 0.80$ & $6.50 \pm 0.84 * *$ \\
\hline
\end{tabular}




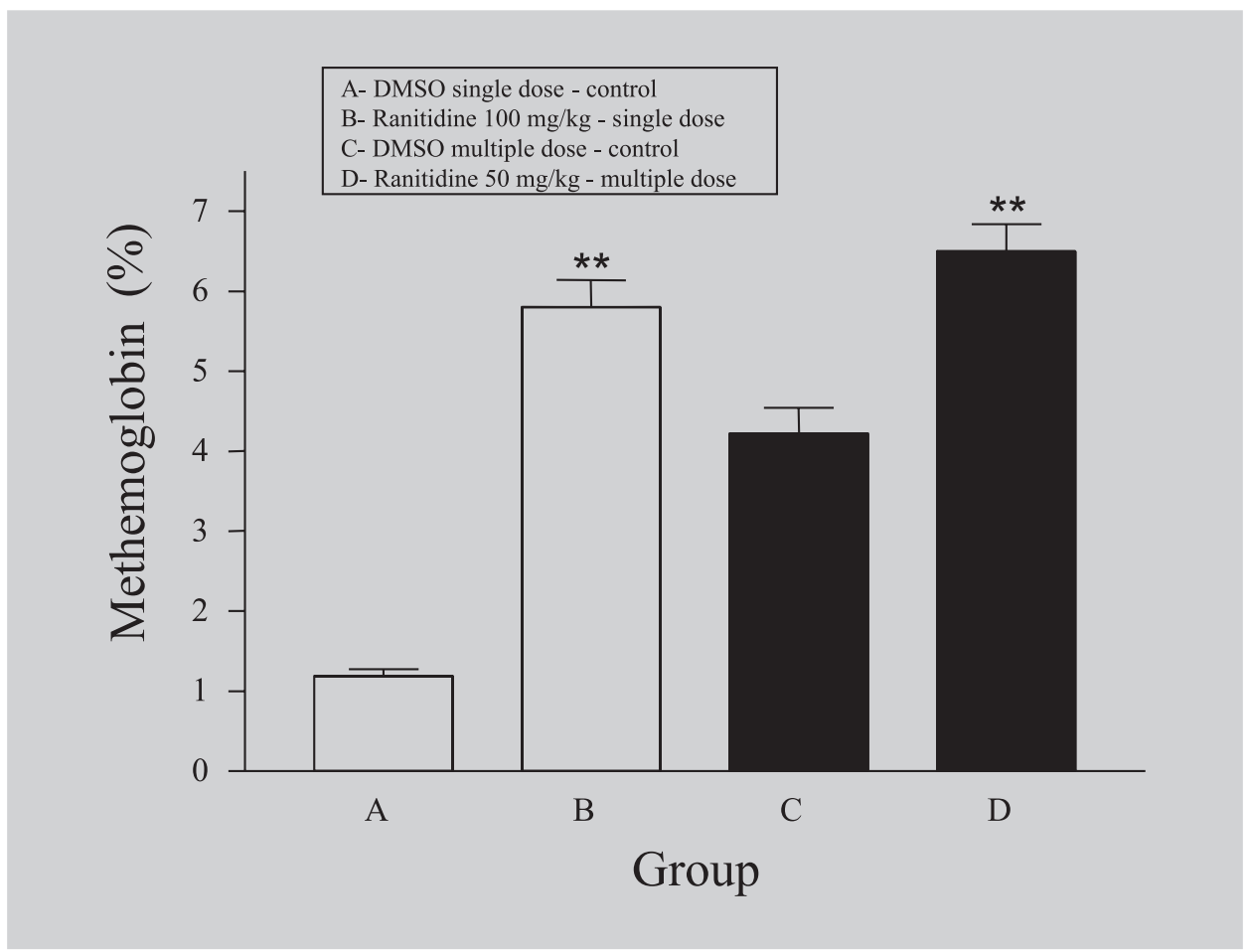

FIGURE 1 - Effect of ranitidine on percent methemoglobin levels in the rats treated with ranitidine $100 \mathrm{mg} / \mathrm{kg}$ in single dose and with ranitidine $50 \mathrm{mg} / \mathrm{kg}$ in multiple dose. $* * \mathrm{p}<0.01$ for the comparison between $\mathrm{B}$ and $\mathrm{D}$ with controls groups A and $\mathrm{C}$, respectively.

TABLE II - Comparison of hematological parameters (white series) for the ranitidine $100 \mathrm{mg} / \mathrm{kg}$ administered in single dose and ranitidine $50 \mathrm{mg} / \mathrm{kg}$ administered in multiple dose with control groups (DMSO).

\begin{tabular}{|c|c|c|c|c|c|c|}
\hline $\begin{array}{l}\text { Hematological } \\
\text { parameter }\end{array}$ & $\begin{array}{l}\text { Control }(\mathrm{n}=6) \\
\mathrm{NaCl} \\
\text { Single dose } \\
\text { mean } \pm \text { SD }\end{array}$ & $\begin{array}{l}\text { Control }(\mathrm{n}=6) \\
\mathrm{NaCl} \\
\text { Multiple dose } \\
\text { mean } \pm \text { SD }\end{array}$ & $\begin{array}{l}\text { Control }(\mathrm{n}=6) \\
\text { DMSO } \\
\text { Single dose } \\
\text { mean } \pm \text { SD }\end{array}$ & $\begin{array}{l}\text { Ranitidine } 100 \\
(\mathrm{n}=6) \\
\text { Single dose } \\
\text { mean } \pm \text { SD }\end{array}$ & $\begin{array}{l}\text { Control }(\mathrm{n}=6) \\
\text { DMSO } \\
\text { Multiple dose } \\
\text { mean } \pm \text { SD }\end{array}$ & $\begin{array}{l}\text { Ranitidine } 50 \\
(\mathrm{n}=6) \\
\text { Multiple dose } \\
\text { mean } \pm \text { SD }\end{array}$ \\
\hline Leukocytes $\left(\mathrm{mm}^{3}\right)$ & $6.465 \pm 1.12$ & $7.155 \pm 1.955$ & $6.833 \pm 1.07$ & $7.320 \pm 1.899$ & $6.979 \pm 989.15$ & $8.567 \pm 900.40$ \\
\hline Neutrophil (mm³) & $2.135 \pm 865.25$ & $2.578 \pm 955.60$ & $2.713 \pm 996.35$ & $2.685 \pm 948.69$ & $2.317 \pm 807.15$ & $2.243 \pm 675.53$ \\
\hline
\end{tabular}

Ranitidine $100 \mathrm{mg} / \mathrm{kg}$-ranitidine in single dose, Ranitidine $50 \mathrm{mg} / \mathrm{kg}$-ranitidine in multiple dose, SD-standard deviation

in the absence of other hepatic abnormalities, but is more commonly associated with an acute hepatitis or cholestatic reaction to the drug. However, some of these reactions are accompanied by a generalized granulomatous reaction.

Other reported side effects have associated ranitidine with hematological abnormalities including granulocytopenia, thrombocytopenia and hemolytic anemia. Agranulocytosis or neutropenia, although of rare occurrence may be severe, even life-threatening. Adverse reactions to drugs are thought to be a common cause of neutropenia; however their study is difficult because they are not predictable and lack of an animal fit for their study.

Autoimmune thrombocytopenia is also related to treatment with ranitidine. The appearance of this condition calls for the interruption of all medication given to the patient; should this not be possible, drugs in use should be changed. In general, platelet counts rise within 7 days, but this effect may be delayed; patients should be handled in a standard manner. Once a patient has demonstrated sensitivity to the drug, its future use should be carefully avoided.

Choo et al. (1994) demonstrated that hemolytic anemia associated with ranitidine is of rare occurrence. Such toxicity is uncommon, but may be exceedingly sever leading to a rapidly fatal outcome in otherwise healthy patients. 
The second set of adverse reactions is a predictable intensification of the intended pharmacological response caused by the use of high doses or overdoses of the drug. Such reactions are in general experimentally reproducible, and dose dependent. In the present study, in order to determine hematological alterations caused by ranitidine, we administered the drug in concentrations of $100 \mathrm{mg} / \mathrm{kg}$ (single dose) and of $50 \mathrm{mg} / \mathrm{kg}$ (multiple doses), and evaluated hematological parameters in the rat.

There was no significant difference in the red blood cells series. In our study, we could find no evidence that ranitidine induce hemolytic anemia. Only one animal presented evidences of hemolytic crisis (not shown). Discrete increment of leukocyte count was observed, but differences in the white blood cells series were not significant. The levels of methemoglobin were significantly increased in comparison to those of control groups.

\section{CONCLUSION}

The results obtained showed that ranitidine can causes increased methemoblobinemia in the administered doses, suggesting that from a certain concentration and dosage scheme the substance can be methemeglobinemia inductor.

\section{RESUMO}

\section{Metemoglobinemia induzida pela ranitidina em ratos}

A idiossincrasia a fármacos é um evento adverso de origem desconhecida, que acontece em poucas pessoas. É conhecido que a ranitidina, um antagonista de receptores $\mathrm{H} 2$, causa reações idiossincrásicas. Para investigar uma possivel indução da ranitidina em relação a hemotoxicidade, o fármaco foi administrado intraperitonealmente (i.p.) em dois de seis grupos de ratos machos Wistar ( $n=6)$, pesando entre 200-220 g. O grupo I recebeu $200 \mu \mathrm{L}$ de solução salina ( $\mathrm{NaCl}$ ) por via intraperitoneal (i.p.), o grupo II recebeu $200 \mu \mathrm{L}$ de $\mathrm{NaCl}$ durante quatro dias consecutivos, o grupo III (controle do veículo,) recebeu $200 \mu \mathrm{L}$ de dimetilsulfóxido (DMSO) em dose única, o grupo IV (controle do veículo) recebeu $200 \mu \mathrm{L}$ de DMSO, durante quatro dias consecutivos, o grupo $V$ recebeu $100 \mathrm{mg} / \mathrm{kg}$ de ranitidina em $200 \mu \mathrm{L}$ de DMSO em dose única, o grupo VI recebeu $50 \mathrm{mg} / \mathrm{kg}$ de ranitidina em $200 \mu \mathrm{L}$ de DMSO durante quatro dias consecutivos. Realizou-se eritrograma, leucograma e determinação da porcentagem de metemoglobina por espectro- fotometria. A porcentagem de metemoglobinemia aumentou de forma significativa em ambos os grupos tratados. A contagem de neutrófilos mostrou uma discreta redução nos regimes de tratamento, ocasionada provavelmente pela mobilização marginal dos mesmos. No regime de doses múltiplas, observou-se aumento no número de leucócitos, mas seu perfil de manutenção de distribuição permaneceu o mesmo. A ranitidina induziu a formação de metemoglobinemia nas doses administradas, sugerindo que a partir de uma certa concentração e ou esquema de dosagem, o fármaco pode ser um indutor do processo.

UNITERMOS: Ranitidina. Metemoglobinemia. Anormalidades hematológicas.

\section{ACKNOWLEGEMENTS}

We thank FAPESP (Fundação de Amparo à Pesquisa do Estado de São Paulo) for financial support.

\section{REFERENCES}

AYMARD J.P.; AYMARD B.; NETTER P.; BANNWARTH B.; TRECHOT P.; STREIFF F., Haematological adverse effects of histamine H2-receptor antagonists. Med. Toxicol. Adverse Drug Exp.,Auckland, v.3, p.430-448, 1988.

COATES, C.A. Routine testing in hematology In: RODAK, B.F., (Ed.). 2. ed. Diagnostic Hematology. New York:W.B. Saunders Co, 1995. p.127-143.

COLEMAN M.D.; TINGLE M.D.; PARK B.K. Inhibition of dapsone-induced methaemoglobinaemia by cimetidine in the rat during chronic dapsone administration. $J$. Pharm. Pharmacol., London, v.43, p.186-90, 1991.

CHOO P.W.; GOLDBERG J.H.; PLATT R. Ranitidineassociated autoimune hemolytic anemia in a health maintenance organization population. J.Clin. Epidemiol., Oxford, v.47, p.1175-79, 1994.

FISCHER A.A. AND LE COUNTEUR D.G. Nephrotoxicity and hepatotoxicity of histamine $\mathrm{H} 2$ receptor antagonists. Drug Saf., Mairangi Bay, v.24, p.39-57, 2001.

GELWAN J.S.; SCHMITZ R.L.; PELLECCHIA C. Ranitidine and leukocytosis. Am. J. Gastroenterol., New York, v.81, p.685-7, 1986. 
GROSSMAN S.J.; JOLLOW D.J. Role of dapsone hydroxylamine in dapsone induced hemolytic anemia. $J$. Pharmacol. Exp. Ther., Baltimore, v.244, p.118-25, 1988.

LEWIS J.H. Hepatic effects of drugs used in the treatment of peptic ulcer disease. Am. J. Gastroenterol., New York, v.82, p.987-1003, 1987.

LUYENDYK J.P.; MADDOX J.F.; COSMA G.N.; GANEY P.E.; COCKERELL G.L.; ROTH R.A. Ranitidine treatment during a modest inflammatory response precipitates idiosyncrasy-like liver injury in rats. J.Pharmacol.Exper.Therap., Baltimore, v.307, n.1, p. 916, 2003.

MERYN S.; POTZI R.; BRUNNER H.; PESENDORFER F.X.; PAMPERL H. Side effects and safety of the new histamine $\mathrm{H} 2$ receptor antagonist ranitidine in the longterm treatment of patients with stomach and duodenal ulcers. Wien. Klin. Wochenschr., Wien, v.29, n.95, p.3102, 1983.

MIKAWA K.; AKAMATSU H.; NISHINA K.; SHIGA M.; MAEKAWA N.; OBARA H.; NIWA Y. The effects of cimetidine, ranitidine, and famotidine on human neutrophil functions. Anesth. Analg., Cleveland, v.89, p. 218-24, 1999.
MUNOZ-ARREBOLA P.; MADRID J.A.; SALIDO G.M.; MARTINEZ DE VICTORIA. E. Modifications of gamma-glutamyl transpeptidase activity in duodenal mucosa of rats treated with different antiulcer drugs. Arch. Int. Physiol. Biochim., Liege, v. 97, p.231-4, 1989.

NAKADA Y.; YAMAMOTO K.; KAWAKAMI J.; SAWADA Y.; IGA T. Effect of renal failure on neurotoxicity of ranitidine in rats. Biol. Pharm. Bull., Tokyo, v.19, p. 323-5, 1996.

PENSTON J.; WORMSLEY K.G. Adverse reactions and interactions with H2-receptor antagonists. Med. Toxicol., Newtown, v.1, p.192-216, 1986.

TAKEUCHI M.; KAGA M.; KIGUCHI M.; IWATA M.; YAMAGUCHI M.; SHIMPO K.; TANABE T. Chronic toxicity study of ranitidine hydrochloride orally administered in rats. Toxicol. Sci., Oxford, v.8, suppl.1, p. $25-49,1983$.

VIAL T.; GOUBIER C.; BERGERET A.; CABRERA F.; EVREUX J.C.; DESCOTES J. Side effects of ranitidine. Drug Saf., Mairangi Bay, v.6, p.94-117, 1991.

Recebido para publicação em 06 de abril de 2004. Aceito para publicação em 21 de outubro de 2004. 